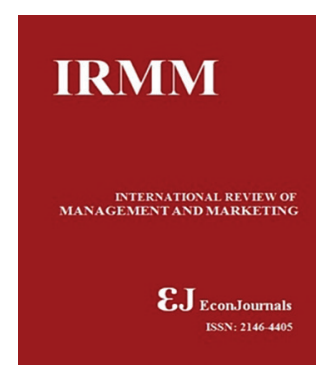

\title{
International Review of Management and Marketing
}

ISSN: $2146-4405$

available at http: www.econjournals.com

International Review of Management and Marketing, 2019, 9(4), 95-99.

\section{Strategic Decision Making and Organization Performance: A Literature Review}

\author{
Hamzeh M. Alhawamdeh¹, Mohammad A. K. Alsmairat ${ }^{2 *}$ \\ ${ }^{1}$ Department of Management Information System, College of Business Administration, Jerash University, Jordan, ${ }^{2}$ Department of \\ Business Management, Luminus Technical University College, Jordan. *Email: moh_cis2004@yahoo.com
}

Received: 10 March 2019

Accepted: 21 June 2019

DOI: https://doi.org/10.32479/irmm.8161

\begin{abstract}
This paper aims to present and discuss the astrategic dissicion making and organization performance, by a review of the relevant literature has shown that a large number of previous studies have attempted to focuse on the importance of strategic dissicion making, in addition to what it is impact on the organization's performance. However, this study contributes to the understanding of factors, which influence managers, decision and performance like environment factors, leadership behavior, organizational justice, decision approach and process. The study concluded by reviewing the literature and previous studies indicate that the strategic decision-making process plays an important role in the effective performance of the organization. The studies also showed that the internal and external environmental factors that affect the performance of the managers to make strategic decisions, As well as, the using of decision support systems help decision-makers in providing the required information in time, which helps to raise the performance of the strategic decision that a direct impact on performance of the organization.
\end{abstract}

Keywords: Strategic, Decision-making, Organizational Performance, Strategic Decision

JEL Classifications: M10, M15

\section{INTRODUCTION}

Organizational performance is one of the most important topics in management research in addition to is the most important criterion in evaluating organizations, their actions, and environments, this importance is reflected in the pervasive use of organizational performance. Organization's performance have been measured substantially based on their profit achievement. None of any organizations wanted to have losses being marked for their business operations during the given accounting period. Thus, managers in the organizations were urged to make profit in the course of business operations, and at the end of their business accounting period. Behind those profits, managers have to make strategic decisions in charting their organization's path in achieving its objectives as directed by the board and top management. Managers needed information in order for them to make a good business decisions. Although, the managers had substantial information prior to make decisions, they may not come up with the right or perfect strategic decision making for the organizations.

However, decision-making is the one of the most important functions of managers in any kind of organization (Nooraie, 2012. p. 405). It is central managerial activity in all types of business organizations; large and small, for profit and not - profit, private and public (Elbanna and Child, 2007. p. 562). Strategic decisions, when implemented correctly, are an opportunity to reposition and realign an organization to better "fit" (Harrison, 1996). Accordingly, successful strategic decision making enables an organization to maintain competitive position, align internal operations with external environment and survive threats and challenges, while conversely, because of their magnitude, a single, poorly made strategic decision can lead to the demise of an organization and result in corporate embarrassment, large economic losses for stakeholders or even bankruptcy (Mueller et al., 2007. p. 853). 
Moreover, all organization members must be involved if they are to understand the need for creativity and if they are to be committed to changing their behaviour at work, in new and improved ways (Singh, 2009; Kingir and Mesci, 2010). Manager's involvement in decision-making serves to create a sense of belonging among the workers as well as a congenial environment in which both the management and the workers voluntarily contribute to enhance organization performance (Noah, 2008).

Therfore, this paper aimed to adrees the relationship between strategic decision making and organization's performance. Moreover, this paper will give the insight of strategic decision making among managers in the Jordanian organizations. How do mangers exercise their strategic decision-making in relation to the organization's performance?

\section{LITERATURE REVIEWS}

\subsection{Managerial Functions}

Effective management involve creative problem solving, motivating employees and making sure the organization accomplishes objectives and goals with height performance. There are five functions of management planning, organizing, commanding, coordinating, and controlling (Robbins and Coulter, 2005). Thus strategic decision makings are involved in mangers during the operations of an organization. Managers have to make thousands of strategic decisions in order to keep their organization in the pace of business. With the rapid development of the organizations in the world with a globalization, the managers should thinking to exploit all the available opportunities to eliminate the threats facing the organization's (McLaughlin and McLaughlin, 2007).

Therefore, the manager's work through the different managerial functions on appropriate strategic decision-making, which contributes to keep the survival of organization in the market and competitive position in the market. Also the cooperation in managerial functions, contributes to raise the level of performance within the organization.

\subsection{Strategic Decision Making}

Decision-making is a process that occurs daily in homes, schools, political, and governmental organizations, corporate boardrooms and executive offices. Decisions, especially important decisions, are made by leaders and managers located at the top of the organizational hierarchy (Hickson et al., 1986). By definition, decision-making is the process through which managers identify organizational problems and attempt to resolve them (Bartol and Martin, 1994). In the words of Harris (2009) decision making involves an act of identifying and ably selecting among an array of alternatives based on the inclination. Its includes variety of processes that are all intermediate steps between thought and action which are the precursors to behavior (Talley, 2011).

Strategic decision-making is an attempt to plan for the long-term future of an organization and increase the odds that the organization will be successful Strategic decision-making is a specific type of decision-making that is "important in terms of the actions taken, resources committed, or the precedent set (Eisenhardt and Zbaracki, 1992) in addition to Strategic decisions are a specific type of decision, as opposed to tactical decisions and operational decisions (Bess and Dee, 2008). (Mintzberg et al., 1976) explain the essence of strategic decisions: A strategic decision process is characterized by novelty, complexity, and open-endedness, by the fact that the organization usually begins with little understanding of the decision situation it faces or the route to its solution, and only a vague idea of what that solution might be and how it will be evaluated when it is developed. Only by groping through a recursive, discontinuous process involving many difficult steps and a host of dynamic factors over a considerable period of time is a final choice made."

The purpose of strategic management is to contribute to finding ways to improve the organization's performance. This contributes to the strategic decision to take the direction of organization and determine its ability to keep its position in the light of the environment in which they can be predictable. (Tatum et al., 2003) state that managers make day-to-day decisions, or resolve immediate problems. They also elaborated that managers have different decision styles due to the amount of information, number of alternatives, and attempt to integrate and coordinate multiple sources of input. Nevertheless, the managers can take the right strategic decision through the decision-making process, which help to ensure the efficiency of the strategic decision. Elbanna and Child (2007) notes that strategic decision-making process (SDMP) deals with the process of making the strategic decision, implementation and the factors that affect the process.

\subsection{Decision Making Process}

Decision makers and managers need to allow themselves to be in the process of decision-making. This decision making process will give the opportunity to decision makers and managers to come up with the alternatives, evaluate each alternatives, and select the best alternative or solution to the problem. Many studies in the field of strategic decision-making describe the process as a sequence of steps, phases or routes. Several impediments have been identified in the way of a correct definition of the issue which is the subject of decision: Paying attention to effects and not to causes, selective perception, defining problems through solutions etc. (Cornescu et al., 2004).

The seven steps followed by the author (Litherland, 2013) are: Defining the problem, identifying and limiting the factors, development of potential solutions, analysis of the alternatives, selecting the best alternative, implementing the decision and establishing a control and evaluation system. This process represents the most commonly one used by the managers. The process of making strategic decisions has been an important theme of strategy research over the last two decades (Papadakis and Barwise, 2002). (Barnard, 1938) distinguished earlier between "logical" and "non logical" processes as bases for decision-making. (Mintzberg et al., 1976) identify three phases of strategic decisionmaking: "Identification," "development," and "selection."

The identification phase involves two routines, decision recognition and diagnosis. Decision recognition involves identifying 
opportunities, crises, and problems that lead to decision activity. There are two routines within the development phase, search and design (Mintzberg et al., 1976). The search routine involves such behaviors as searching the memory of the organization, passively waiting for a solution to appear, announcing to outsiders that a solution is needed in hopes of an answer, and finally actively searching for solutions. When the search routine fails the design, routine begins; failure to find a "ready-made" solution leads to the "custom-made" design of one. Typically, organizations design only one custom-made solution - as opposed to the time consuming work of designing several only to discard all but one. Most decision-making resources are deployed and used during the search and design routines of the development phase as compared to other routines and phases in the cycle.

The selection phase has three sequential routines: "Screen," "evaluation-choice," and "authorization" (Mintzberg et al., 1976). Screening seems to be an implicit part of the process; alternative solutions are eliminated in a rapid review according to feasibility and appropriateness. Different theoretical models of strategic decision processes, which reflect different conceptions of organization, have been suggested by various literatures. The models that definitely differ substantially in terms of their underlying assumption about the decision context and the characteristics of decision process are usually influenced by different factors. According to (Nooraie, 2012) the factors affecting the strategic decision-making in particular the different stages and process can be classified into four major categories.

1. Decision-specific characteristics

2. Internal organizational characteristics

3. External environmental characteristics

4. Management team's characteristics.

\subsection{Organization Performance}

Performance lies at the heart of any managerial process and organizational construct and is therefore considered as a critical concept in the strategic management field. It is critical that the managers understand and design strategies to make and select good strategic decision, which lead to obtain a greater performance. Performance as a theoretical construct can be defined as "the accomplishments or outcomes of an entity" (Phillips and Mountinh, 2000). It can be defined also as "the way an organization performs via other similar organizations in its industry, not only on traditional financial indicators of performance, but on important non-financial indicators as well" (Khatri and Ng, 2000). Many researchers agree that organizational performance is a complex, multidimensional phenomenon and a function of many variables (Lytle and Timmerman, 2006).

Anderson, 2004 assessed organizational performance by efficiency and market expansion to reflect overall economic performance, which was measured by self-assessed indicators of an organization's profitability and sales growth compared to its close competitors. (Jurkiewicz and Giacalone, 2004) stipulated that organizational culture will lead to firm performance. Thus, workplace spirituality such as benevolence, generativity, humanism, integrity, justice, mutuality, receptivity, respect, responsibility, and trust will give an impact on individual workers; and will lead to higher productivity and will improve firm performance. Organization high in workplace spirituality outperform those without by $86 \%$. Further, such organizations reportedly grow faster, increase efficiencies, and produce higher returns on investments. This can be triangulated by three areas as such motivation, commitment, and adaptability (Jurkiewicz and Giacalone, 2004).

\subsection{Environment Factors}

The internal and external environment of organizations is changing continuously, which causes challenges for human competence development and management. Most of the quality costs form from poor work practices causing lost labor (Andersson et al., 2004). Environment or external factors influenced strategic decisionmakings, and subsequently affected the organization performance. Mangers made strategic decision-makings based on the external factors that affect their decisions. Porter 1979, created five forces that explained the environmental factors, which affect managers' strategic decision-making (Pearce and Robinson, 1997). The organization must deal with an environment that is determined by the strategic decisions of top management. Apart from that, also listed external environment factors that has an impact on decision making such as Porter's "five-forces," regulatory pressures, emergent technologies, and economic conditions (Provan, 1989). In addition to the Internal factors are the most important factors that influence the process of strategy formulation because it focuses on the goal, and to look at the strengths and weaknesses within the organization (Provan, 1989). (Crook et al., 2003) stated that the Company analysis needs to be considered in the process of strategic decision-making.

\subsection{Decision Approach}

Kohlberg's, 1973 description of ethical decision making as a rational process, where people reason through moral dilemmas by applying moral principles or some other criteria, set the stage for research on ethical decision making for a while. There are three types of rational ethical decision-making models (Sonenshein, 2007). Some of the rational models assume that managers engage in reasoning based on moral theories, such as deontology or utilitarianism, and then act according to the principles of these theories (such as truth-telling as a duty, as per deontology, or benefit to the majority in utilitarianism) (Hunt and Vitell 1984). Other rational models propose that rather than based on moral theory, managers reason according to the stage of their moral development, or based on rewards and sanctions (Treviño and Youngblood, 1990).

The third type of reasoning models are based on "moral intensity": People respond to ethical issues on the basis of differences in the consequences (impact on victims or beneficiaries), consensus about the good or evil of the proposed act, the probability of effect, its temporal immediacy and proximity to its victims or beneficiaries, and other components of moral intensity (Jones, 1991).

\subsection{Leadership Behavior}

Leadership is often a concept that has many different meanings, and there is not a single, communally used definition according to Yukl (2002). According to (Barton and Martin, 1994) we can describe and classify the behavior of the leader based on the degree 
of concern for the people and the output can be specified with the leadership behavior AS:

- Impoverish management: Exertion of minimum effort to get required work done is appropriate to sustain organization membership

- Country club management: Thoughtful attention to needs of people for satisfying relationships leads to a comfortable friendly organization atmosphere and work tempo

- Authority-obedience: Effiaciency in operations results from arranging conditions of work in such a way that human elements interfere to a minimum degree

- Organization man management: Adequate organization performance is possible through balancing the necessity to get out work with maintaining morale of people at a satisfactory level

- Team management: Work accomplishment is from committed people; interdependence through a common stake in organization purpose leads to relationships of trust and respect.

Einarsen et al. (2007) distinguish 4 types of leadership behavior; the distinction between these 4 types has been made based on the two domains: Organization and subordinates.

1. Tyrannical leadership: Where a leader shows antisubordinate behavior, but pro-organizational behavior

2. Derailed leadership: Where a leader shows antisubordinate behavior and anti-organizational behavior

3. Supportive-disloyal leaders: Where a leader shows prosubordinate behavior, but anti-organizational behavior 4 . Constructive leadership: Where a leader shows prosubordinate behavior and pro-organizational behavior.

While the executive professional experiences with the leader affecting the behavior leadership as it helps to make strategic decisions. (So and Smith, 2003) indicated that differences in decision makers' cognitive styles, cognitive abilities and personality are important factors in decision-making and performance. The managers' leadership roles need consider eight suggested questions as they develop a plan, solve a problem, meet a challenge, or seek to exploit an opportunity. The questions to be considered are goals (outcome), communications, participation, competence, satisfaction, co-operation, norms, and reviews (Rausch, 2003).

Larssona and Vinbergb (2010) stated, "Leadership is an important factor for organizations," which shows the role that leadership plays in the journey of success in accomplishing the plans and achieving the goals to make a visible change. The strategic leadership stat is a powerful, visual and conceptual guide to strategic behavior. It focuses the organization on the delivery of value to the customer and highlights the key areas where effort must be continuously directed (Nicholls, 1994). Thus, the management of an organization would simultaneously be performing their strategic leadership role and ensuring the competitive success.

\subsection{Organizational Justice}

Organizational justice has attracted a great deal of attention from management researchers and the importance of organizational justice has been recognized as a fundamental basis for effective cooperative action in the organization (Konovsky, 2000). Organizational justice describes "individuals' and the group's perception of the fairness of treatment (including, but not limited to, allocations) received from an organization and their behavior reaction to such perceptions" (James, 1991). The presence of organizational justice in management decisions is an important indicator of the quality of exchange relationships between individuals and their employing organizations as well as between employees and organizational agents (Tekleab et al., 2005). Organizational justice consider as the ethical treatment of individuals within an organization, and is intimately tied to leadership and decision process. In addition to the organizational justice refers to the structural elements of the organization that allow employees involvement in decisionmaking and provide for the fair distribution of incomes being (Greenberg, 1993).

\subsection{Decision Support Systems (DSS)}

Eom et al., 1998 defined DSS as computerized interactive systems that support decision makers in the decision-making process, utilize data and models, and assist in solving problems with varying degrees of structure. DSSs are typically used for semi-structured or non-structured types of decisions, which many times preclude a "correct" answer, and are in contrast to the nature of structured decisions (Aldag and Power, 1986). Decision makers, whether making a personal or managerial decision, want to feel as though they are making the best decision possible given the available information.

Much of the underlying technologies driving today's DSS take advantage of the Internet, providing decision makers with the rapid dissemination of information (Shim et al., 2002). DSS is an established area of information system applications, which assists the decision makers to derive an in time, efficient solution (Pourvakhshouri and Mansor, 2003). (Majchrzak and Gasser, 2000) indicated that TOP-MODELER ${ }^{\odot}$ can help managers in overcoming the burden of strategic decision making in their daily business operations. The system also assists the managers to understand their organization structure in gaining closest relationship possible.

\section{CONCLUSION}

Strategic decision-makings and managers cannot be separated. They go inline together. Moreover, with the organization's concern on the firm performance, strategic decision-makings are considered crucial to managers that manage the organization. Nevertheless, managers are affected with several factors in their strategic decision-makings for organization. These factors will directly and indirectly affect their well being of the organization. As such, various studies were conducted in looking into various aspects and factors in relation to managers, strategic decisionmakings, and firm performance.

The factors between strategic decision-makings and organization performance will be incorporated as such decision support system these factors will be the catalyst between strategic decision-makings and organization performance. Moreover, this 
research focused on the several factors that influence individual managers in their strategic decision-makings.

\section{REFERENCES}

Aldag, R., Power, D. (1986), Power, an empirical assessment of computer-assisted decision analysis. Decision Sciences, 17(4), 572-588.

Andersson, P.H., Hiltunen, K., Villanen, H. (2004), Promoting Quality in Finnish Companies. Helsinki: Ministry of Trade and Industry, Edita Publishing.

Barnard, C. (1938), The Functions of the Executive. Cambridge, MA: Harvard University Press.

Bartol, K.M., Martin, D.C. (1994), Management. $2^{\text {nd }}$ ed. New York: McGraw Hill, Inc.

Bess, J.L., Dee, J.R. (2008), Understanding college and university organization: Theories for effective policy and practice. Virginia: Stylus. Journal of the Operational Research Society, 49(2), 109-120.

Cornescu, V., Marinescu, P., Curteanu, D., Toma, S. (2004), Management: De la Teorie la Practică. București: Editura Universității din București.

Crook, T.R., Ketchen, D.J. Jr., Snow, C.C. (2003), Competitive edge: A strategic management model. Cornell Hotel and Restaurant Administration Quarterly, 44(3), 44-53.

Einarsen, s., Aasland, M.S., Skogstad, A. (2007), Destructive leadership behavior: A definition and conceptual model. The Leadership Quaterly, 18(3), 207-2016.

Eisenhardt, K.M., Zbaracki, M.J. (1992), Strategic decision-making. Strategic Management Journal, 13, 17-37.

Elbanna, S., Child, J. (2007), Influences on strategic decision effectiveness: Development and test of an integrative model. Strategic Management Journal, 28, 431-453.

Eom, S., Lee, S., Kim, E., Somarajan, C. (1998), A survey of decision support system organizations. Journal of Management, 26(3): 489-511.

Greenberg, J. (1993), The social side of fairness: Interpersonal and informational classes of organizational justice. In: Cropanzano, R., editor. Justice in the Workplace: Approaching Fairness in Human Resource Management. Hilldale, NJ: Lawrence Erlbaum. p79-103.

Harris, A. (2009), Attributions and institutional processing: How focal concerns guide decision-making in the juvenile court. Race and Social Problems, 1(4), 243-256.

Harrison, F. (1996), A process perspective on strategic decision-making. Management Decision, 34(1), 46-53.

Hickson, D.J., Butler, R.J., Cray, D., Mallory, G.R., Wilson, D.C. (1986), Top Decisions: Strategic Decision-making in Organizations. San Francisco: Jossey-Bass Publishers.

James, K. (1991), The social context of organizational justice: Cultural, intergroup, and structural effects on justice behaviors and perceptions. In: Cropanzano, R., editors. Justice in the Workplace: Approaching Fairness in Human Resource Management. Hillsdale, NJ: Lawrence Erlbaum Associates. p21-50.

Jurkiewicz, C.L., Giacalone, R.A. (2004), A values framework for measuring the impact of workplace spirituality on organizational performance. Journal of Business Ethics, 49, 129-142.

Khatri, N., Ng, H.A. (2000), The role of intuition in strategic decision making. Human Relations, 53(1), 57-86.

Kingir, S., Mesci, M. (2010), Factors that affect hotel employees motivation the case of Bodrum. Serbian Journal of Management, 5(1), 59-76.

Larsson, J., Vinberg, S. (2010), Leadership behaviour in successful organisations: Universal or situationdependent? Total Quality Management, 21(3), 317-334.

Litherland, N. (2013), Available from: http://www.ehow.com/ howdoes_5280248_decisionmaking-process-managers.html. [Last accessed on 2013 Feb 02].

Lytle, R.S., Timmerman, J.E. (2006), Service orientation and performance: An organizational perspective. Journal of Services Marketing, 10(2), 136-147.

Majchrzak, A., Gasser, L. (2000), TOP-MODELER@: Supporting complex strategic and operational decision making. Information Knowledge System Management, 2, 5-110.

Mintzberg, H., Raisinghani, D., Theoret, A. (1976), The structure of "unstructured" decision processes. Administrative Science Quarterly, 21(2), 246-275.

Mueller, C.G., Mone, M.A., Barker, V.L. (2007), Formal strategic analyses and organizational performance: Decomposing the rational model. Organization Studies, 28, 853-883.

Nicholls, J. (1994), The strategic leadership star: A guiding lightin delivering value to the customer. Management Decision, 32(8), 21-26.

Noah, Y. (2008), A study of worker participation in management decision making within selected establishments in Lagos, Nigeria. Journal of Social Science, 17(1), 31-39.

Nooraie, M. (2012), Factors influencing strategic decision making processes. International Journal of Academic Research in Business and Social Sciences, 2(7), 405-429.

Nooraie, M. (2012), Factors influencing strategic decision-making processes. International Journal of Academic Research in Business and Social Sciences, 2(7), 1-10.

Papadakis, V.M., Barwise, P. (2002), How much do CEOs and top managers matter in strategic decision-making? British Journal of Management, 13, 83-95.

Pearce, $2^{\text {nd }}$ J.A., Robinson, R.B. Jr. (1997), Strategic Management: Formulation, Implementation, and Control. $6^{\text {th }}$ ed. New York: McGraw-Hill/Irwin. p7-8.

Phillips, P.A., Moutinho, L. (2000), The strategic planning index: A tool for measuring strategic planning effectiveness. Journal of Travel Research, 38(4), 369-379.

Provan, K.G. (1989), Environment, department power, and strategic decision making in organizations: A proposed integration. Journal of Management, 15(1), 21-34.

Rausch, E. (1996), Guidelines for Participating in Appropriate Decision Making. Management Development Review, 9(4), 29-34.

Robbins, S.P., Coulter, M. (2005), Management. $8^{\text {th }}$ ed. New Jersey: Pearson Education, Inc.

Shim, J., Warkentin, W., Courtney, J., Power, D., Sharda, R., Carlsson, C. (2002), Past, present, and future of decision support technology. Decision Support Systems, 33(2), 111-126.

Singh, S.K.G. (2009), A study on employee participation in decision making. Unitar E-Journal, 5(1), 20-38.

So, S., Smith, M. (2003), The impact of presentation format and individual differences on the communication of information for management decision making. Managerial Auditing Journal, 18(1), 59-67.

Tatum, B.C., Eberlin, R., Kotttraba, C., Bradberry, T. (2003), Leadership, decision making, and organizational justice. Management Decision, 41(10), 1006-1016.

Tekleab, A.G., Takeuchi, R., Taylor, M.S. (2005), Extending the chain of relationships among organizational justice, social exchange, and employee reactions: The role of contract violations. Academy of Management Journal, 48(1), 146-157.

Yukl, G. (2002), Leadership in Organizations. New York: Prentice Hall. 